\title{
GEOMORPHOLOGICAL CHARACTERISTICS OF THE SAND- DUNE FIELD OF THE CENTRAL KYPARISSIAKOS GULF
}

\section{Karamousalis Th. ${ }^{1}$, Poulos S. ${ }^{1}$, Maroukian H. ${ }^{1}$, and Ghionis G. ${ }^{1}$}

\author{
${ }^{I}$ National and Kapodistrian University of Athens, Faculty of Geology and Geoenvironment, \\ Department of Geography \& Climatology, Panepistimiopolis, Zografou 157 84, Athens, \\ akexpro@yahoo.com; poulos@geol.uoa.gr;maroukian@geol.uoa.gr;gghionis@otenet.gr
}

\begin{abstract}
Sand dunes are sensitive coastal landforms closely related to the evolution (and/or stability) of the beach zone. The present work refers to the central part of the dune field that lies along the middle part of the shoreline of the Kyparissiakos Gulf. The scope of the present investigation is to reveal the geomorphological and sedimentological characteristics of the sand dune field in association with the natural processes contributing to their formation. On the basis of our findings, the dune field of the central Kyparissiakos Gulf consists of four dune ridges, with heights $>4.0 \mathrm{~m}$. Their extent indicates the availability of large quantities of sand and the existence of a rather stable wind field. They consist of well sorted medium to fine sand. The alluvial fan of the Zachareiko torrential river has covered the dune field in the area of its mouth and buried the oldest $4^{\text {th }}$ dune ridge to its south. The development of the dune field is estimated to have taken place during the last 3-4 thousand years subsequently to the completion of the rapid sea level rise at the end of the last glacial period.
\end{abstract}

Key words: coastal landforms, alluvial fans, dunes.

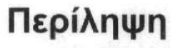

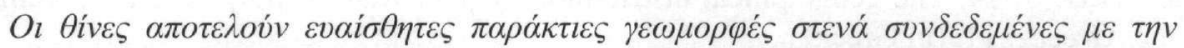

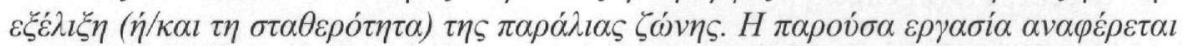

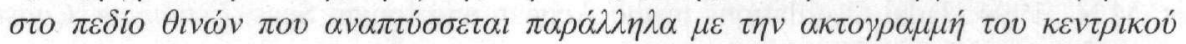

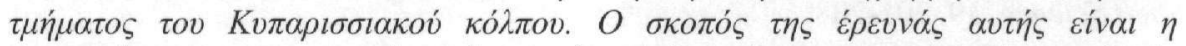

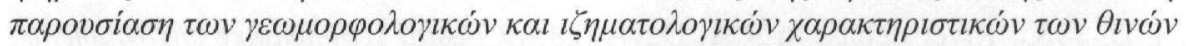

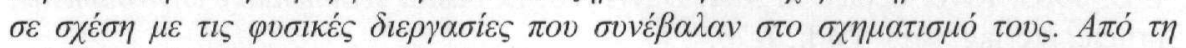

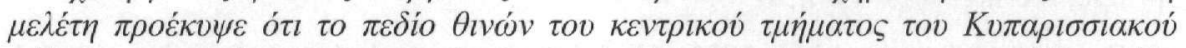

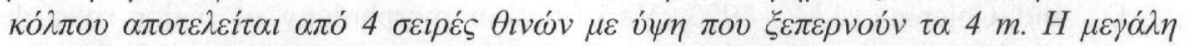

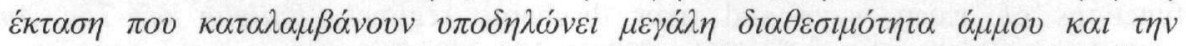

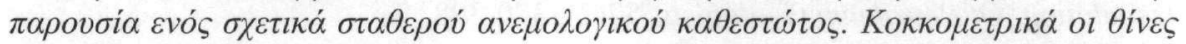

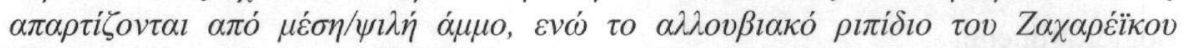

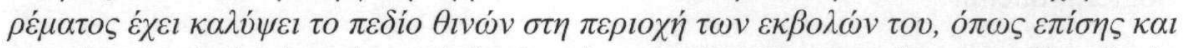

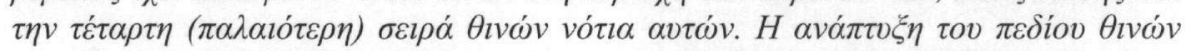

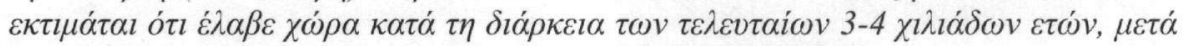

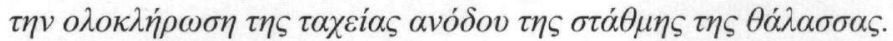

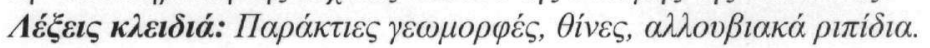




\section{Introduction}

Dunes develop landward of the shoreline, usually above the high tide level, wherever dry sand is in sufficient supply and onshore winds exceed a minimum velocity; they are often perceived to mark the landward limit of marine influence on the coasts (Haslett 2000). Sand dunes are formed when sand is blown landwards from the dry portion of the beach until either wind energy is dissipated or a physical obstruction causes the sand grains to accumulate. The presence of vegetation denotes the commencement of the sand stabilization process.

In terms of their morphometry, dunes have been classified into four major types (Hesp 2000): (i) foredunes, (ii) blowouts, (iii) parabolic dunes and (iv) transgressive dune fields.

Foredunes are parallel to the shore, convex, symmetric to asymmetric dune ridges, formed on the backshore zone by deposition of wind-blown sand. They generally are of two main types: incipient (newly formed foredunes with sparse vegetation) and established (older, more permanent foredunes with woody plant species and usually presenting a greater complexity of form, height and width). Blowouts are erosional features in the form of saucer-, cup-, bowl- or trough-shaped depressions and/or hollows, formed by wind erosion of a pre-existing sandy substrate or sand dunes. Parabolic dunes are U- or V-shaped dunes, with a roughly parabolic outline. They are characterized by trailing ridges which terminate downwind in a parabolic-shaped depositional lobe. They may be active or relict (i.e. fully vegetated) and they typically evolve from blowouts. Trangressive dune fields are relatively large scale aeolian sand deposits formed by the downwind and/or alongshore movement (or transgression) of sand over a fully to semi -vegetated terrain.

Dunes of varying size and extent are present on many Greek coasts, such as the coasts of northern Crete, Attica, SW Corfu, etc., but their spatial extent is more pronounced along the $60 \mathrm{~km}$ of shoreline of the Kyparissiakos Gulf.

The purpose of the present investigation is to examine the geomorphological characteristics of the sand dune field of the central Kyparissiakos gulf and to reveal their importance with respect to the coastal environment.

\section{The Study Area}

The dune field under investigation is located in the central part of the Kyparissiakos Gulf, immediately to the south of the Kaiafa lagoon, and has a length of approximately $5 \mathrm{~km}$ (Fig. 1).

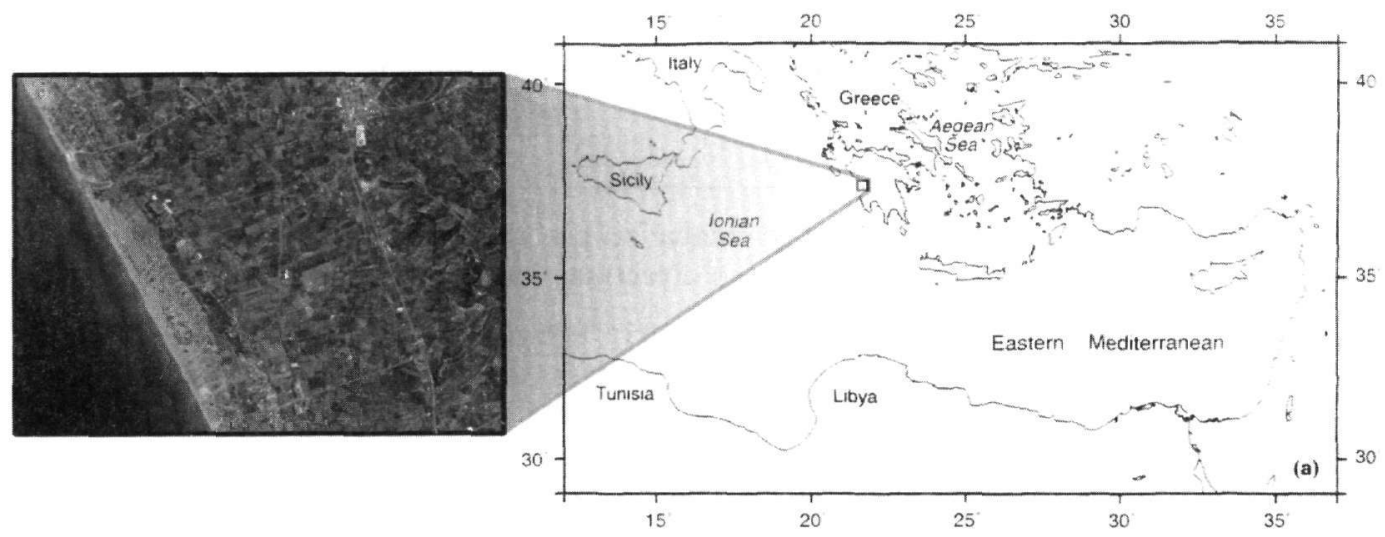

Figure 1 - A satellite image of the investigated sand dune field in the central part of the Kyparissiakos Gulf (western Greece)

Kyparissiakos gulf, on the western coast of Peloponnesus, comprises a riverine-coastal system that has developed near the tectonically active Hellenic subduction zone, thus experiencing intensive 
tectonism. The Alpine basement of the studied area belongs mainly to the Pindos geotectonic zone, which is characterised by pelagic series of thin-bedded limestones, radiolarites and flysch. At Mount Lapithas, $7 \mathrm{~km} \mathrm{NE}$ of the Kaiafas lagoon, the tectonically lower neritic series of Tripolis zone is visible, consisting of dark, compact limestones and flysch.

The dune field under investigation, Holocene in age, overlies post-Alpine Quaternary marine sediments, which consist mainly of marls, sands, silts and clays and are overlain, in places, by terrestrial sediments (Fig. 2).

The Kyparissiakos Gulf receives the freshwater and sediment inputs primarily of the River Alfios (to the north of the study area) and secondarily of the smaller rivers Peristera, Neda and a number of ephemeral streams that debouch at the central and southern part of the gulf. The coastal zone is characterised by the presence of fine-grained sediments, mostly sand (Alexouli-Leivaditi 1990).

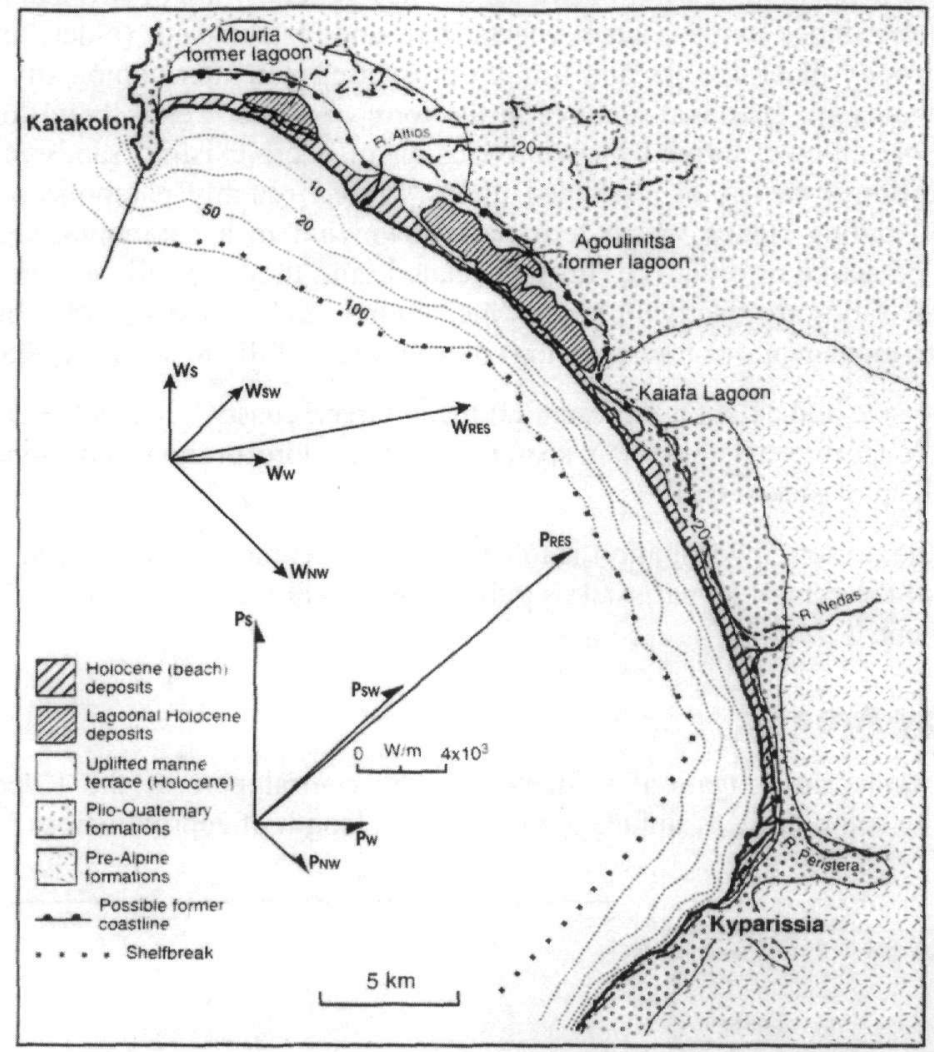

Figure 2 - Map showing a simplified geological map of the area and the resultant wind ( $W_{\text {RES }}$ ) and wind-induced wave power $\left(P_{R E S}\right)$ directions (originally from Poulos et al. 2002)

Tidal ranges rarely exceed $10 \mathrm{~cm}$ (Tsimplis et al., 1995). The gulf is exposed to NW, W, SW and S winds which induce waves with maximum heights in excess of $5 \mathrm{~m}$. The resultant wave power is directed almost to the NE, whilst the resultant wind speed is towards the ENE (Fig. 2). The incoming waves have formed sub-aqueous oblique welded bars and the net longshore sediment transport in the central part of the gulf is towards the North (Poulos et al. 2002).

\section{Materials and Methods}

The present investigation is based upon information obtained from topographic maps (scale 1:5.000) and aerial photographs provided by the Geographical Service of the Hellenic Army, as well as a series of photographs, in situ observations and the analysis of surficial sediment samples 
collected during two field campaigns (March 2005 and April 2005). The locations of two cross sections across the dune field and of the surficial sediment samples along a line parallel to section B-B' are shown in Figure 3.

Analyses of sediment samples have been conducted according to Folk's (1974) procedure, statistical elaboration and interpretation of the results. ArcGIS software has been used for the digitization of the topographic data and the production of a 3-D terrain model.

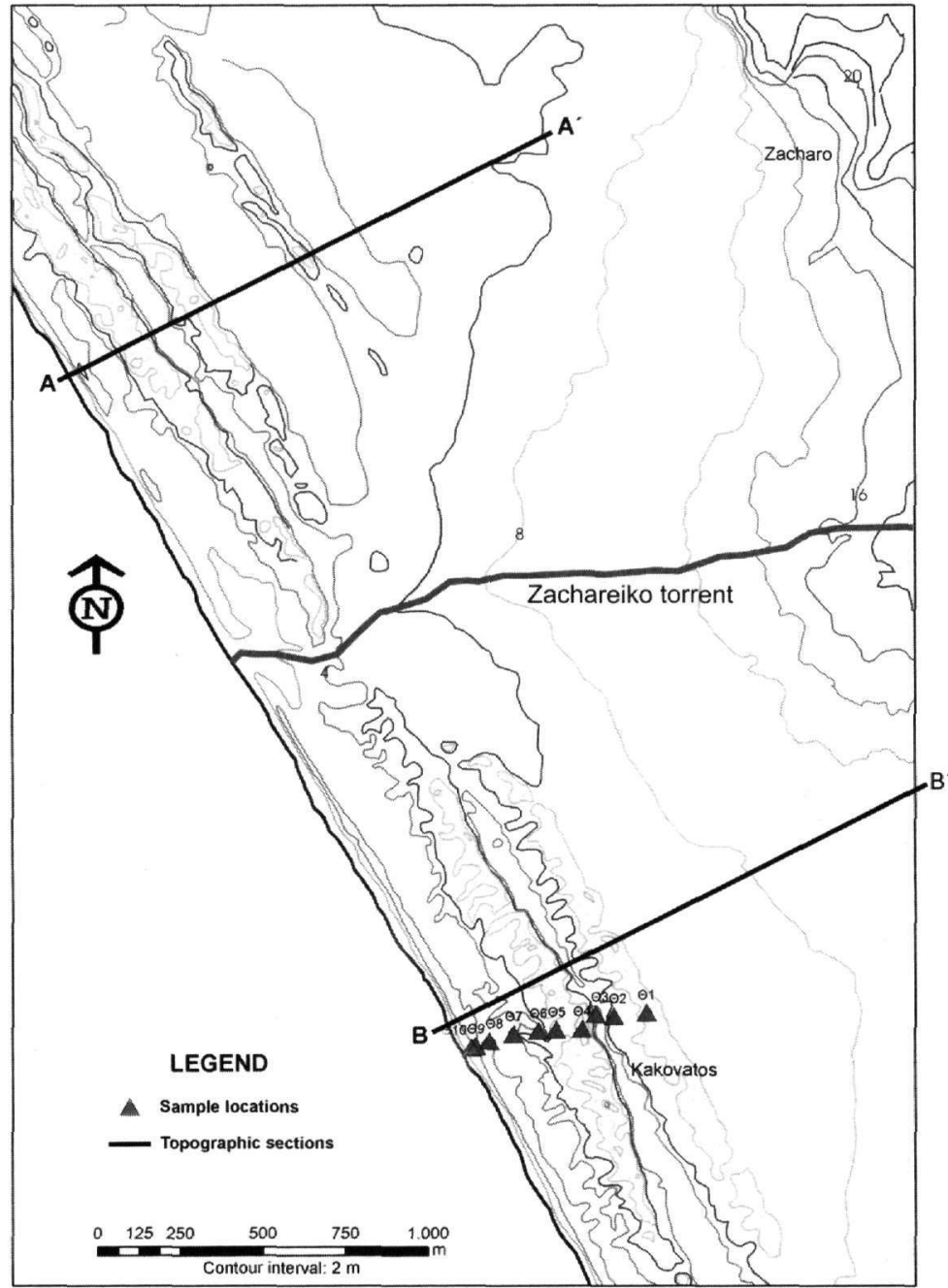

Figure 3 - Map showing the two WSW-ENE topographic sections A-A' and B-B' and the location of the sediment samples $(\Theta 1-\Theta 10)$ collected for grain size analysis

\section{Results and Discussion}

The dune field of the central Kyparissiakos Gulf includes three to four dune ridges which have a direction parallel to the shoreline (Fig. 3). The first and most recently formed dune ridge which is the landward limit of the beach zone, has the characteristics of a foredune, scarped in many places by the wave action during severe storm events. The distance between the foredune and the shoreline varies, but rarely exceeds $25 \mathrm{~m}$. In general, the beach zone seems to be rather stable and the foredune (mean height: $4.50 \mathrm{~m}$, max. height $6.90 \mathrm{~m}$ ) is covered by sparse vegetation. 


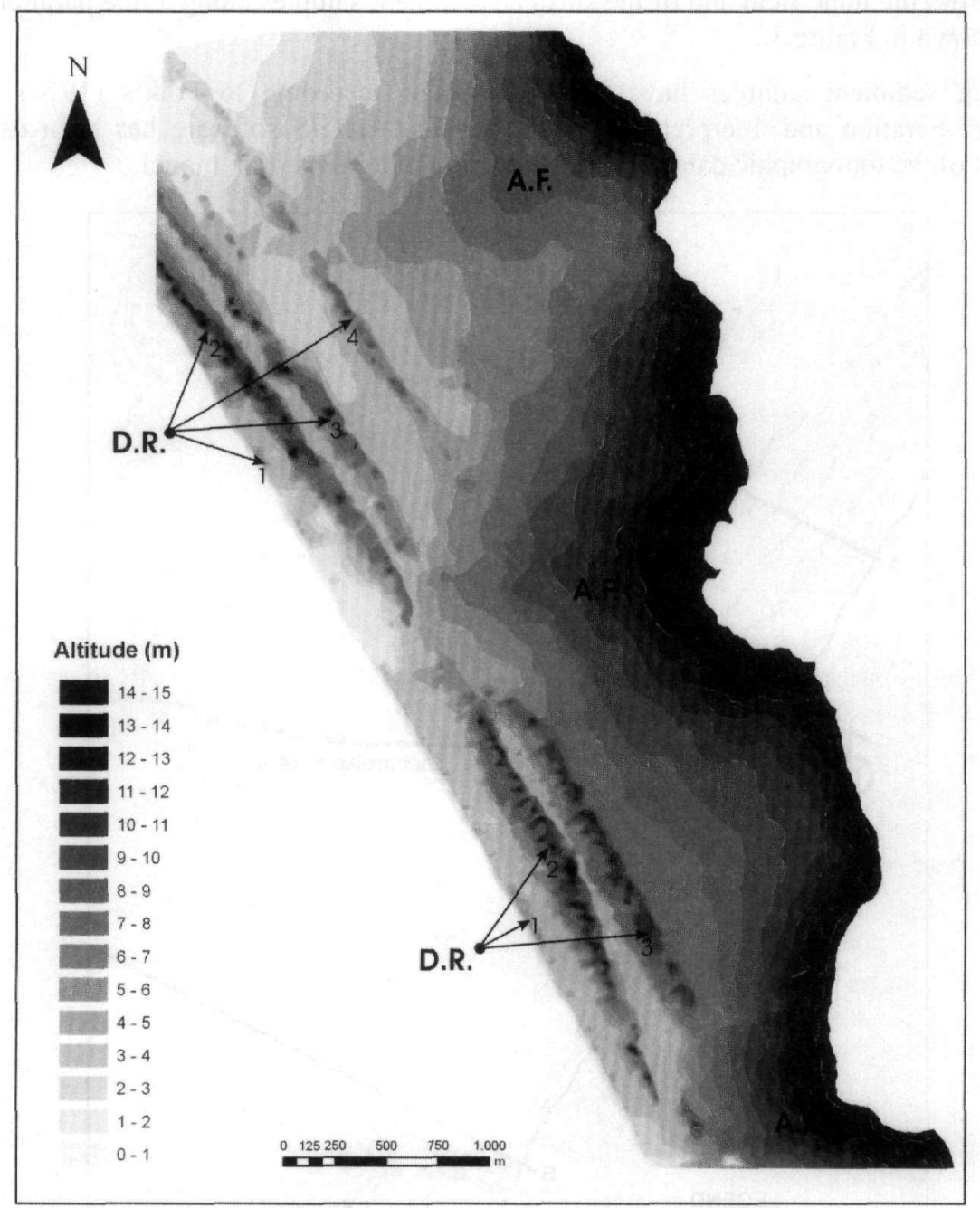

Figure 4 - A 3D relief model of the study area (D.R.: dune ridge; A.F.: alluvial fan)

Two to three parallel dune ridges, stabilized by vegetation (pine trees, shrubs, etc.), exist landwards of the foredunes. Their mean and maximum heights are given in Table 1 and their shape is shown in Figure 5.

Table 1 - Mean and Maximum Height of the Dune Ridges

\begin{tabular}{|c|c|c|}
\hline Dune Ridge & Mean Height $(\mathbf{m})$ & Maximum Height $(\mathbf{m})$ \\
\hline $1^{\text {st }}$ Ridge & 4.5 & 6.9 \\
\hline $2^{\text {nd }}$ Ridge & 12.5 & 16.1 \\
\hline $3^{\text {rd }}$ Ridge & 12.0 & 13.0 \\
\hline $4^{\text {th }}$ Ridge & 8.5 & 9.5 \\
\hline
\end{tabular}




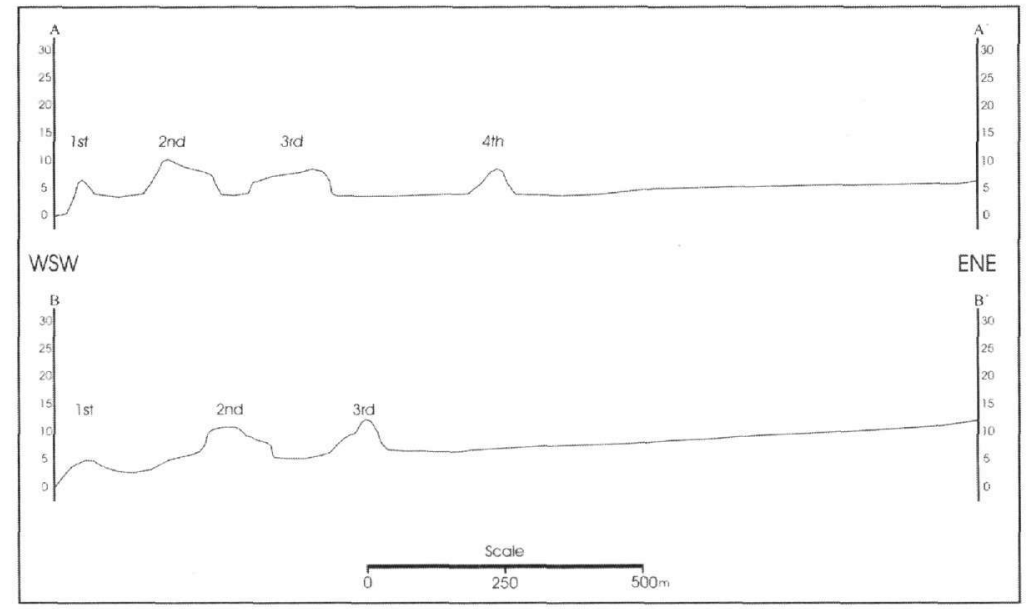

Figure 5 - Topographic cross-sections A-A' and B-B' across the dune-field (for location see Fig. 3)

Occasionally, ephemeral ponds are formed in the lowland areas (called slacks), between the dune ridges. In these areas, vegetation is more dense and diverse due to the proximity of the water table and the sand is usually moist, so that it cannot be blown off easily and aeolian erosion is inhibited.

Dune ridges are characterized by many blowout forms whose axes have a predominant SSW-ENE direction. This direction coincides with the resultant wind stress (see Fig. 2), indicating a stability of the wind regime during the evolution of the sand dunes. The vertical extent of blowouts is restricted by the water table (moist sand).

The formation of multiple ridges of dunes is due to the large input of sediment originating mainly from the south, following the completion of the rapid phase of sea level rise around $5000 \mathrm{BP}$, and under the influence of strong $\mathrm{W}$ and SW winds.

The hinterland area, behind the dune fields, is characterised by the presence of prograding alluvial fans, with the biggest one formed by the Zachareiko torrential river. This river has cut through the dune ridge system and its alluvial fan has partially covered the dune ridges in the vicinity of the river and almost completely buried the eastern $\left(4^{\text {th }}\right)$ ridge on the southern side of the river (Fig. 4). The alluvial fans started prograding soon after the completion of the main phase of the last sea transgression. They may also have evolved over older lagoons, which were associated with the formation of barrier beaches and dune ridges. Today, such lagoons are the existing Kaiafa lagoon and the artificially drained lagoons of Agoulinitsa and Mouria in the area of the Alfios river delta.

The sediment samples taken from the dunes consist almost exclusively of sand ( $>99 \%)$ having sizes between $1.7 \varphi$ and $2.0 \varphi$. All samples are well sorted, with inclusive graphic standard deviation $\left(\sigma_{\mathrm{I}}\right)$ values ranging between 0.35 and $0.55 \varphi$ (Table 2). This indicates a stability of the prevailing wind regime and the availability of similarly sized sandy material over a long period of time.

The dune filed in the central Kyparissiakos Gulf is under environmental pressure, as the older $3^{\text {rd }}$ and $4^{\text {th }}$ dune ridges have been occupied by man. For example, the village of Kakovatos is located partially on the second and third dune ridges. Furthermore, some recreational development has taken place along the foredune, with pathways crossing the dune and along the lee side of the dune. Moreover, it is known that, essentially, the dunes act as a sediment depot, protecting the hinterland from storm erosion and potential sea level rise and they are the natural habitat for specially adapted plants and animals, several of which are now rare or endangered. Hence, the local authorities should be very careful when planning and/or implementing development plans, whilst it could be wiser not to intervene with the natural evolution at least of the foredune. 
Table 2 - Statistical parameters of the grain size samples

\begin{tabular}{|c|c|c|c|c|}
\hline Sample & $\begin{array}{l}\mathbf{M}_{z} \\
(\varphi)\end{array}$ & $\begin{array}{c}\sigma_{\mathrm{I}} \\
(\varphi)\end{array}$ & Sorting & $\begin{array}{c}\text { Grain size } \\
\text { nomenclature } \\
\text { Folk (1974) }\end{array}$ \\
\hline$\Theta 1$ & 2.00 & 0.38 & Well sorted & $\mathrm{S}$ \\
\hline$\Theta 2$ & 1.96 & 0.48 & Well sorted & $\mathrm{S}$ \\
\hline$\Theta 3$ & 1.95 & 0.40 & Well sorted & $\mathrm{S}$ \\
\hline$\Theta 4$ & 1.94 & 0.42 & Well sorted & $\mathrm{S}$ \\
\hline$\Theta 5$ & 1.97 & 0.36 & Well sorted & $\mathrm{S}$ \\
\hline$\Theta 6$ & 1.90 & 0.46 & Well sorted & $\mathrm{S}$ \\
\hline$\Theta 7$ & 1.74 & 0.55 & Moderately well sorted & $\mathrm{S}$ \\
\hline$\Theta 8$ & 1.90 & 0.42 & Well sorted & $\mathrm{S}$ \\
\hline$\Theta 9$ & 2.00 & 0.35 & Well sorted & $\mathrm{S}$ \\
\hline$\Theta 10$ & 1.82 & 0.35 & Well sorted & $\mathrm{S}$ \\
\hline$\Theta 11$ & 1.71 & 0.47 & Well sorted & $\mathrm{S}$ \\
\hline
\end{tabular}

\section{Conclusions}

The dune field of the central Kyparissiakos Gulf consists of four dune ridges, with heights $>4.00 \mathrm{~m}$. The first dune ridge from the shoreline is a foredune whilst the other ridges have blowout erosional forms. They consist of medium to fine well sorted sand. Their development indicates the availability of large quantities of sand and the prevalence of a rather stable wind field. The alluvial fan of the Zachareiko torrential river has covered the dune field and buried the oldest $4^{\text {th }}$ dune ridge to its south. The development of the dune field is estimated to have taken place during the last 3-4000 years and certainly after the completion of the rapid sea level rise at the end of the last glacial period $(\approx 5000$ years BP). Nowadays, great attention should be given to the protection and conservation of the dune field and especially the foredune zone.

\section{Acknowledgments}

The authors greatly appreciate the financial support of Mr. and Mrs. Alexandropoulos during this investigation and their continuous assistance in retrieving historical data, old maps and recent borehole data for the area.

\section{References}

Alexouli-Livaditi, A., 1990. Sedimentological and mineralogical investigations in the sediments of the beaches of Kyparissiakos Gulf, Proceedings of the $3^{\text {rd }}$ Symposium of Oceanography and Fisheries, Athens, 14-17 May 1990, 124-146pp. (in Greek)

Folk, R.L., 1974. Petrology of Sedimentary Rocks, Hemphill Publishing Company, Austin, Texas, 183 pp.

Haslett, S.K., 2000. Coastal Systems, Routledge, London, 218pp.

Hesp, P.A., 2000. Coastal sand dunes. Form and function, CDVN Technical Bulletin, No 4. 28pp. 
Poulos, S.E., Voulgaris, G., Kapsimalis, V., Collins, M., and Evans, G., 2002. Sediment fluxes and the evolution of a riverine-supplied tectonically-active coastal system: Kyparissiakos Gulf, Ionian Sea (eastern Mediterranean). In S.J. Jones and L.E. Frostick (eds), Sediment Flux to Basins: Causes, Controls and Consequences, Geological Society, London, Special Publications, 191, 247-266.

Tsimplis, M.N., Proctor, R., and Flatcher, R.A., 1995. A two- dimensional tidal model for the Mediterranean Sea, Journal of Geophysical Research, C8, 223-216. 